\title{
Pedagógusok tapasztalatai a tanulók motiválásáról a Covid19 járvány idején
}

\author{
Józsa Gabriella ${ }^{1}$, Karáné Miklós Noémi ${ }^{2}$ és Józsa Krisztián ${ }^{3}$ \\ ${ }^{1}$ Debreceni Egyetem, Humán Tudományok Doktori Iskola, Neveléstudományi Program; \\ Kecskeméti SZC Kandó Kálmán Technikum \\ ${ }^{2}$ Petöfi Sándor Katolikus Gyakorló Általános Iskola és Óvoda \\ ${ }^{3}$ Szegedi Tudományegyetem Neveléstudományi Intézet; \\ Magyar Agrár-és Élettudományi Egyetem Neveléstudományi Intézet
}

\begin{abstract}
Absztrakt
A tanulmány a vírushelyzet következtében létrejött online oktatáshoz kapcsolódóan vizsgálja a tanulási motivációt. A kérdőíves adatfelvételben 160 pedagógus vett részt, akik az általános iskola alsó és felső tagozatán, valamint középiskolában tanítanak. A kutatás célja az volt, hogy feltárja a pedagógusok vélekedését a diákok motiváltságáról a digitális oktatás során. Összehasonlítottuk, hogy a tanulók motiváltságában milyen különbséget látnak a pedagógusok az osztálytermi és a digitális oktatás során. Megvizsgáltuk, hogy a pedagógusok mennyire tartják hatékonynak az online térbe helyezett oktatás során alkalmazott motivációs stratégiáikat. Elemeztük, hogy a motiválási módszerek hatékonyságában milyen különbségek mutatkoztak meg az alsó és felső tagozat, valamint a középiskola között. Megvizsgáltuk továbbá, hogy a pedagógusok miként vélekednek saját motiváltságukról a digitális oktatáshoz kapcsolódóan, és ez milyen összefüggésben van tanítványaik motiváltságával. A tanuló iskolafokozata mellett további elemzési szempontunk volt a pedagógus gyakorlottsága, magabiztossága az IKT-eszközök használatában, valamint az intézmény településtípusa.
\end{abstract}

Kulcsszavak: digitális oktatás, tanulási motiváció, pedagógusi vélekedések

\section{Bevezetés}

A koronavírus okozta világjárvány miatt egyik napról a másikra bevezetésre kerülő digitális munkarend nagy kihívás elé állította a pedagógusokat, a diákokat és a szülőket egyaránt. Az oktatási intézmények bezárásával szükségessé vált a jelenléti oktatásról a digitális környezetben megvalósuló tanításra, tanulásra történő átállás. A diákok motiválása tantermi oktatás során sem egyszerü feladat, azonban személyes jelenlét nélkül még nehezebbé vált megtalálni azokat a módszereket, eszközöket, melyekkel a motiváció fenntartása sikeressé 
válhat. A pedagógusok többségének nem volt korábbi tapasztalata ezen a területen. Tanulmányunk központi kérdése ezért az, mennyire hatékonyan tudták a pedagógusok motiválni tanítványaikat a digitális munkarend idején.

A digitális munkarend azt jelenti, hogy a személyes jelenlétű oktatásról, tanulásról távoktatásra, különféle digitális eszközök használatára tér át az oktatás minden szereplője. Ez megköveteli, hogy mind a pedagógusok, mind a tanulók gyakorlottak legyenek a digitális eszközök tanulási célú használatában, és még ennél is alapvetőbb követelményként merül fel az ehhez szükséges eszközök megléte. Az eszközellátottság mellett a család, a szülök részvétele, támogatása is kritikus jelentőséggel bír az otthontanulásban, a motiváció fenntartásában (Garcia \& Weiss, 2020). A „digitális oktatás legnagyobb kihívása ott tartani a gyereket a képernyő előtt" nyilatkozta Székely Erika, egy kétgyermekes édesanya Ambrus és munkatársai (2020) összeállításában. „Egyik éjszaka arra riadtam, vajon jó helyre töltöttem-e fel a matematika munkafüzet negyvennegyedik oldalát" - emlékszik vissza a szülő. A tapasztalatok ugyanakkor azt mutatják, hogy sok diák mellett nem is volt segítő szülő vagy azért, mert nem tudtak segíteni, vagy azért, mert érdektelenek voltak (Ambrus, 2020). Mindezt tovább nehezíti az a tény, hogy a közoktatásban töltött évek elörehaladtával a legtöbb diák tanulás iránti motiváltsága csökken. Kutatások szerint, minél magasabb évfolyamra jár egy tanuló, annál kevésbé lelkesedik az iskolai tanulás iránt (Józsa et al., 2020).

\section{Digitális oktatás}

A digitális innovációk alkalmazása az oktatásban már jó pár éve megjelent hazánkban is. Az Európa 2020 stratégiában szó van a digitális kompetencia fejlesztéséről, az új módszerek alkalmazásáról (Török, 2013), majd 2016-ban a Kormány elfogadta Magyarország Digitális Oktatási Stratégiáját (DOS), azóta számos tanulmány látott napvilágot a digitális oktatásról és a hozzá kapcsolódó fejlesztésekről (például Fehér, 2020; Molnár et al., 2020). Több kutatás is felhívta a figyelmet arra, hogy a digitális eszközhasználat jelentős mértékben hozzájárulhat a tanulás hatékonyságához, és növelheti a tanulók motiváltságát is (például Molnár \& Csapó, 2019; Szabó et al., 2020). A digitális terek a mai ifuúság számára természetes miliőént jelennek meg, azonban kevés tanuló tudja hasznosan beépíteni ezen innovációkat saját tanulási folyamataiba (Námesztovszki et al., 2013).

Az UNESCO adataiból tudjuk, hogy 2020 tavaszán a világjárvány miatt 188 ország függesztette fel jelenléti oktatását (Váradi \& Józsa, 2021), hazánkban is egyik napról a másikra kellett megtenni a digitális átállást az oktatás minden szintjén. A köznevelési intézmények igyekeztek kidolgozni saját digitális stratégiájukat, melyben a fó kérdés az volt, milyen rendszerek és módszerek lesznek a legmegfelelőbbek az otthoni tanulási folyamat támogatására. Ebben az egyik alapvető kérdés az volt, a nevelőtestületek milyen platformot választanak az online oktatás színteréül, ahol a tartalom ered- 
ményes átadása, közvetítése a tanulók felé már a pedagógusok egyéni, felelősségteljes szakmai döntése, feladata volt. A digitális pedagógia tervezési folyamatainál előtérbe került a rendelkezésre álló eszközök feltérképezése, a képességek fejlesztése, az érdeklődés fenntartása. Törekedni kellett arra, hogy a tanulók ne csak passzív hallgatói, befogadói, hanem aktív használói, fogyasztói legyenek a digitális tartalmaknak (Lénárd, 2020). Az online oktatásban való részvétel, az online tanulás egy sajátos viselkedésformát igényel: egyrészt fontos az elköteleződés az online tanulás iránt, másrészt kulcsfontosságú tényező az önszabályozás képessége (Ithriah et al., 2020).

A járványhelyzet online pedagógiája rávilágított a hazai oktatás negatívumaira és pozitívumaira egyaránt. Mindenki számára láthatóvá váltak a korábbi oktatáskutatói figyelmeztető előrejelzések. A digitális eszköz önmagában csak színes szemléltetőeszközként funkcionál, ha nem megfelelő módon és környezetben használják. Csupán az eszközpark korszerüsítésével nem nőnek a pedagógiai eredmények. Emellett sok esetben egyértelművé vált az eszközhasználathoz kapcsolódó tudás hiánya, amely nehezítette a digitális környezetben való tanítást és tanulást. Nyilvánvalóvá vált az is, hogy a „digitális bennszülöttek" többsége jóval elörébb jár a digitális kompetenciák fejlettségében, mint a korfáját tekintve elöregedő pedagógustársadalom zöme. Azok az iskolák tudtak igazán jól és hatékonyan működni ebben a krízishelyzetben, ahol a pedagógusok gyorsan, innovatívan és rugalmasan tudtak alkalmazkodni a megváltozott helyzethez, a digitális világhoz (Jakab, 2020).

A digitális oktatásra való átállás felgyorsította a reformok terjedését, olyan módszerek meghonosodását, amelyek a fejlett oktatási rendszerű országokban már bevált szokásként vannak jelen. Ide tartozik többek között a felfedező tanulás, problémaközpontú tanórák, egyéni tanulási útvonalak biztosítása, ahol a pedagógus mint segítő, facilitátor jelenik meg (Prievara, 2020). A rendszeresség, a kiszámíthatóság, a türelmes környezet egyaránt előmozdítja a diákok tanórai aktivitását az online térben is. Az órai aktivitás akkor bizonyul fenntarthatónak, ha mindenkit sikerül bevonni a tanulási folyamatba, az óra menetébe, ha állandó visszajelzést, visszacsatolást és értékelést kapnak a tanulók. A tapasztalatok azt mutatják, hogy előremutató a gamifikáció (játékosítás) alkalmazása, ami a különböző számítógépes játékés játéktervezési elemek használatát jelenti a tanítás folyamatában. Célja az extrinzik és az intrinzik motiváció ötvözése az elkötelezettség, a motiváció és az aktivitás elősegítése (Kyewski \& Krämer, 2018).

A pedagógusok az online oktatáshoz kapcsolódóan pozitív és negatív tapasztalatokról egyaránt beszámoltak. Voltak, akik megnövekedett munkateherről és a sikerélmény csökkenéséről számoltak be. Nőtt a kiégés veszélye, a túlterheltség, a kiszámíthatatlanság. A magánélet teljesen összefolyt a munkahelyi tevékenységekkel, feladatokkal. Mindezek azért is veszélyt jelentenek a pedagógustársadalomra, mert a hatékonyságot befolyásolhatja a mentális, pszichés állapot. Pozitív tapasztalatként többen a tanár-diák interakciók növekedését emelték ki. Pozitívumként jelent meg az új pedagó- 
giai módszerek alkalmazása, melyek közül kiemelkedett a változatos online platformok használata, videók megtekintése, munkafüzeti feladatok online térbe helyezése. A pedagógusok úgy tapasztalták, nehézzé vált a tanulók teljesítményének értékelése, enyhébb osztályzatok születtek, és feltételezhetö, hogy romlott a tanulás hatékonysága (N. Kollár, 2021). A pedagógusok és a szülők egybehangzóan úgy ítélik meg, hogy az olvasástanítás az osztálytermi tanításhoz viszonyítva kevésbé hatékony a digitális munkarend időszakában (Józsa \& Pasztendorf, 2021). A tanulói teljesítmények visszaesését tesztekkel végzett mérések is kimutatták. Az olvasás-szövegértés, a matematika és a természettudományok területén az átlagos tudás- és képességszint alacsonyabb volt, mint az előző két tanévben (Molnár et al., 2021).

Kassa Tünde (2020) gyakorló pedagógus szerint minőségi változás volt érzékelhető a 2020 márciusában, illetve a 2020 őszén kezdődő digitális oktatásban. Feltehetően elindult a pedagógusok körében az IKT-eszközök magabiztosabb használata, illetve már sem a tanulók, sem a pedagógusok nem feltérképezetlen környezetbe kerültek. Mindezek ellenére a hazai oktatás tekintetében még mindig nehezíti az online oktatás folyamatát a digitális módszertani hiányosság (Cifrusz et al., 2020). Vannak olyan, az iskolában használatos módszerek, amelyeket sikeresen lehet integrálni az online világba, azonban legtöbbször a siker érdekében el kell térni az osztálytermi környezetben bevált gyakorlattól. Az eddigi tapasztalatok szerint az egyik legfontosabb a sikeres digitális oktatás megvalósulásában a tanár-diák kommunikáció. A leghatékonyabb módszernek a hibrid oktatás mutatkozik, amely élőhívásos órák megtartását és önálló munkavégzést, tanulást egyaránt magában foglal. A felsőoktatásban tanuló hallgatókkal végzett vizsgálatok is rámutatnak az oktatókkal és társakkal folytatott valós idejü interakciók jelentőségére az online oktatás során (Asztalos et al., 2021). A tapasztalatok szerint az egész napos online élőhívásban megtartott tanítási órák heti öt napon keresztül motiválatlanná teszik a tanulókat, mert ezzel elveszti a digitális oktatás azon pozitívumát, amely az önálló tanulásra sarkall, önszabályozást segíti elő. Kiemelten jó módszernek bizonyul az érdeklődés fenntartására a „break-out room” használata csoportbontásokra, a kutatómunkák és projektfeladatok alkalmazása, illetve az így létrejött diákmunkák bevonása a tananyagba (Kassa, 2020).

\section{Motiváció és online tér}

A világjárvány megfékezése érdekében az oktatási intézmények is bezárásra kényszerültek, azonban a tanítás, tanulás nem szünetelt, hanem online oktatás formájában folytatódott az általános iskola alsó tagozatától egészen az egyetemi oktatásig. Több országban kedvezményeket tettek a diákok értékelésében a járványidőszak alatt (például Franciaország, Spanyolország stb.), amit egyfelől igazságos döntésnek véltek, másfelöl aggodalommal fogadtak, ugyanis a motiváció csökkenését eredményezheti. Ennek oka, hogy az osz- 
tályzatok motiválhatják a diákokat a tanulásra (Di Pietro et al., 2020). Köztes megoldást választott például az észt Oktatási Minisztérium, mely felszólította az iskolákat, hogy a távoktatásra való átállás első pár hetében mellőzzék a tanulók teljesítményének értékelését (Err, 2020). Voltak olyan országok is, ahol nem voltak adottak a digitális távoktatás feltételei. Kenyában például úgy döntöttek, semmisnek tekintik és megismétlik a teljes tanévet, azaz, minden tanuló arra az évfolyamra iratkozott be újra, amire egy évvel korábban is járt.

Összehasonlító vizsgálatok mutattak rá, hogy az online térben sikeresen tanuló diákok lényeges jellemzője a belső motiváltság (Shroff \& Vogel, 2009; Wighting et al., 2008), mely összefüggést mutat az önszabályozással (Hartnett, 2016). Digitális környezetben a technológiát önmagában motiválónak tekintik, hiszen az újdonság erejével hat, megmozgatja a fantáziát, kihívást jelent, felkelti az érdeklődést. Ezen jellemzők összessége az, ami miatt segít a motiváció előmozdításában (Lepper, 1985). Azonban a digitális eszközök használata a motiváció csökkenését is magában rejti. Egyrészt elvész az újdonság ereje, amint a tanulók megszokják a technológiát, másrészt a technikai problémákkal szembeni frusztráció csökkentheti az online térben való tanulás iránti motiváltságot. A jelenléti oktatással összehasonlítva online környezetben magasabb a lemorzsolódás veszélye (Hartnett, 2016). Az ARCS (attention, relevance, confidence, satisfaction) modell szerint az online környezetben történő motiváláshoz is szükséges (1) a tanuló figyelmének fenntartása a kíváncsiság, érdeklődés, izgalom által, amit érdekes grafikák, animációk válthatnak ki. Azonban egy idő után a diákok ezt megszokják és elvesztik érdeklődésüket. (2) A világos célok meghatározása, a relevancia kulcsfontosságú eleme a motiválásnak. A tanulás iránti erősebb motiváció akkor érhető el, amikor a tanuló szabadon választhat a számára hasznosnak tűnő tevékenységek között. (3) A motiváció úgy valósulhat meg, ha sikerélményhez juttatjuk a tanulókat, vagyis olyan körülményeket teremtünk, ahol sikereiket saját képességeiknek és erőfeszítéseiknek tulajdonítják, nem pedig a szerencsének vagy a túl könynyünek feladatnak. (4) Végül az elégedettség szükséges ahhoz, hogy a tanulók pozitívnak érezhessék tanulási tapasztalataikat. Ez azt jelenti, hogy olyan külső megerősítéseket kell használni, amik nem károsítják a belső ösztönzőket. Ilyen lehet például a személyes elismerés. Továbbá fontos, hogy a diákoknak érezniük kell, hogy a befektetett munka mennyisége összhangban van a célokkal, a tartalommal és a számonkéréssel (Keller \& Suzuki, 2004).

A pedagógus személyisége, kompetenciái, pozitív visszacsatolásai és azok minősége meghatározóak a tanulók motiváltságában. A hatékony tanulás feltétele online térben is a megfelelő motiváció, amely során a pedagógus felkelti a figyelmet, ráhangolja tanulóit a tananyagra és tudásszomjukat a megfelelő mederben terelgeti. Energetizál, aktivizál, irányít és integrál egyben, amely végig kell, hogy kísérje az egész tanítási-tanulási folyamatot (Námesztovszki et al., 2013).

Az eddigi tapasztalatok alapján a tanulók motiváltságára online térben a következők hatottak pozitívan: különböző szemléletes, interaktív appliká- 
ciók beépítése a tanulási folyamatokba, tervezhetőség, tudatos szervezés és időbeosztás, változatos feladatok elvégzése, folyamatos tanári visszacsatolás, értékelés, illetve mindezekkel szorosan összefüggve különböző oktatási platformok kipróbálása (Fegyverneki, 2017).

A digitális oktatás számos előnyt kínál az idősebb, önálló tanulók számára: személyre szabhatják tanulásukat, lehetőségük van irányítani saját tanulási folyamataikat, megérteni, hogy mit akarnak megtanulni és milyen támogatásra van szükségük hozzá. Az online tér nagyobb rugalmasságot biztosít azáltal, hogy saját tempójukban tudnak tanulni. Azonban ezek az előnyök a fiatalabb diákok számára nem elérhetők, hiszen még nem tudják megszervezni tanulási tevékenységüket, időgazdálkodásuk és önszabályozásuk még fejletlen, ezért nem tudják kiaknázni a távoktatás előnyeit. Ezenkívül a pedagógusok felkészültsége és pozitív hozzáállása kulcsfontosságú eleme az online térben való tanulás sikerének. A digitális térben oktatóknak képesnek kell lenniük kompenzálni a fizikai jelenlét hiányát, ahol minden résztvevő jól érzi magát, és a tanárok könnyen elérhetőek a diákok számára a motiváció fenntartása és a tanulás eredményessége érdekében (Di Pietro et al., 2020).

A digitális átállás is rámutatott a magyar oktatási rendszerben erőteljesen jelen lévő szelekciós mechanizmusokra, továbbá megfigyelhetővé vált a családi háttér iskolai eredményességben betöltött szerepe. Nőttek a társadalmi egyenlőtlenségek, csökkent az esélykiegyenlítés lehetőségének megteremtése. A társadalom rétegződését figyelembe véve, a magasabb szocioökonómiai státuszú családokban nevelkedő gyermekek extra előnyökhöz jutottak, amely nem volt másként az online oktatás előtt sem (Fekete \& Porkoláb, 2020). A kedvezőtlenebb családi háttérrel rendelkező diákok korlátozott hozzáféréssel bírnak az online oktatáshoz szükséges eszközökhöz, illetve az internetes szolgáltatásokhoz való hozzáférésük is korlátozott, melyet a szakirodalom "digitális megosztottság”-nak nevez (García \& Weiss, 2020). Ezek a gyermekek nagyobb eséllyel vannak kitéve stresszes otthoni környezetnek, például nagyobb valószínűséggel kell osztozniuk más családtagokkal a digitális eszközön vagy a szobán, melyben tanulnak. Emellett azok a szülők, akik a pandémia miatt pénzügyi és munkahelyi bizonytalanságba, netalán válságba kerültek, valószínüleg kevésbé tudták gyermekeik tanulását, tanulás iránti elköteleződését támogatni (Di Pietro et al., 2020; Porubčanová et. al., 2021).

A családi támogatásnak az otthoni tanulás során döntő szerepe van. Engler és munkatársainak (2021) vizsgálatában a tanulókkal való otthoni együtt-tanulás gyakorisága nem függött a szülők iskolai végzettségétől. Hasonló eredményre jutottak Szilveszter és munkatársai (2021) is, miszerint önmagában a szocioökonómiai státusz nem szignifikáns előrejelzője a tanulás sikerességének, azonban a tanulásba fektetett erőfeszítés, családi rutin és rendezettség igen. Láthatjuk tehát, hogy az online oktatás feltételeinek megteremtéséhez szükséges a család gazdasági és kulturális tőkéjének megléte, azonban Engler és munkatársainak (2021) véleménye szerint ebben a különleges helyzetben minden szülő igyekezett gyermeke tanulmányi előmenetelét előmozdítani. 
Eredményük azt mutatja, hogy az otthoni tanulást leginkább a családdal való minőségi együtt töltött idő határozta meg.

Porubčanová és munkatársai (2021) által írt monográfia az ókorig viszszanyúlóan ad áttekintést az otthoni tanulás történeti előzményeiről. Az otthontanulás, otthonoktatás nem jelentett teljesen ismeretlen helyzetet a pandémia időszakának kezdetén. Napjainkig kiható módon a 70-es évek Amerikájában kezdett elterjedni, 2012-ben az iskoláskorú gyermekek 3,4\%a tanult ilyen formában az USA-ban (Ray, 2017). Az egyes országok eltérő módon viszonyulnak az otthonoktatáshoz. Néhány országban, mint például Norvégia, Kanada, Új-Zéland, azért döntenek az otthonoktatás mellett, mert az iskola nagy távolságra van a gyermekek otthonától. Más országokban a formális oktatástól való félelem (például agresszió, szerfogyasztás, vallás) okán tartják távol a gyermekeket az intézményes oktatástól. Mindezek mellett a számítógép és internet elterjedése jelentősen segítette az otthonoktatás lehetőségének megteremtését (Mihály, 2006). A hazai otthonoktatás melletti döntés hátterében megtalálható az iskolarendszerrel szembeni kritika, az iskolában szerzett rossz tapasztalat. A szülő pozitív otthonoktatás élménye, de az otthonoktatás melletti döntés általában a szülők társadalmi státusán és személyes érzésén alapul (Veszprémi, 2020). A hazai otthonoktatás gyakorlatáról, előnyeiről és hátrányairól Nágel (2012) adott áttekintést. Az otthonoktatás ezen szakmai tapasztalatai szélesebb körben nem ismertek, így a digitális munkarend bevezetése során ezekre kevéssé lehetett támaszkodni.

\section{Az empirikus vizsgálat célja és módszerei}

\section{A vizsgálat célkitüzései}

Vizsgálatunk célja, hogy feltérképezzük a pedagógusok véleményét a diákok motiváltságának alakulásáról az online oktatás időszakában a jelenléti oktatáshoz viszonyítva. Kutatásunk legfontosabb kérdése, vajon érzékelnek-e a pedagógusok különbséget a tanulók motiváltságában az osztálytermi és a digitális oktatás között? Elemzésünkben összehasonlítjuk a köznevelés különböző szintjein - alsó- és felső tagozaton, valamint középiskolában - tanító pedagógusok tapasztalatait ezen a téren.

\section{A vizsgálat körülményei}

Az adatgyüjtés online kérdőíves módszerrel történt 2021. április elején. Az adatfelvétel időszakában, 2021. március 8-tól minden iskolafokozaton digitális munkarend volt életben. Ennek köszönhetően a kérdőívek kitöltése során a pedagógusoknak a digitális oktatásról napi tapasztalata volt, mert egy hónapja már így tanítottak, az osztálytermi oktatásról pedig visszaemlékezés alapján formáltak véleményt. Megjegyezzük, hogy ez már a második digitális oktatási időszak volt, a korábbira 2020 tavaszán került sor. A pedagógusok- 
nak tehát már volt korábbi tapasztalata az előző tanévből ezen a téren. Az adatgyüjtéshez kényelmi mintavételi technikát alkalmaztunk (Gliner et al., 2017). A válaszadás önkéntes és anonim volt.

\section{A vizsgálat mintája és eszköze}

Az online kérdőív első része a tanulási motiváció fenntartásával és a jelenléti oktatással való összehasonlításával foglalkozik. A második részben a különféle háttérváltozókra kérdeztünk rá. A kiértékelés és elemzés kvantitatív módszerrel történt.

A kérdőívet összesen 160 pedagógus töltötte ki. A válaszadók 92\%-a nő. Ez az arány összhangban van azzal, hogy az általános iskolákban tanító pedagógusok 87\%-a volt nő 2017-ben, a középiskolákban a férfi tanárok aránya magasabb, ott eléri az egyharmadot (Tóth, 2019), a nők túlsúlya minden képzési szinten meghatározó. A válaszadók közül a legtöbben nagyvárosban dolgoznak (40\%). Közel azonos arányban érkeztek válaszok a fővárosban (19\%) és középméretű városban (18\%) dolgozóktól, illetve hasonló arányban dolgoznak kisvárosban (12\%) és községben (11\%) is.

A pedagóguséletpálya-modell szerinti a következőképpen oszlott meg a minta: gyakornok (11\%), pedagógus I. (34\%), pedagógus II. fokozatban (44\%), mesterpedagógus (10\%), kutatótanár (1\%). Ezek az arányok jó közelítéssel megfelelnek a pedagógusok életpályamodell szerinti megoszlásának. Az elemzéseinkhez két kategóriát képeztünk a pedagógusokból. A gyakornokokat és a pedagógus I. fokozatban lévőket nevezzük kezdő pedagógusoknak, ők a minta 45\%-a. A pedagógus II., a mesterpedagógus és a kutatótanár fokozatokat nevezzük gyakorlott pedagógusnak, ez a kategória a minta 55\%-a.

Az iskolafokozatot tekintve az alsó tagozaton tanítók adják a kitöltők 61\%át, felső tagozaton tanító pedagógus a válaszadók 26\%-a, középiskolai tanár pedig 13\%. Az önkéntes válaszadás alapján kapott mintázatból úgy tünik, hogy a magasabb iskolafokon tanító pedagógusok esetében némileg kisebb a válaszadási hajlandóság. Mindemellett mindhárom kategóriában kellően nagy a válaszadók száma ahhoz, hogy statisztikailag elemezhető legyen.

\section{Eredmények és értelmezés}

\section{Osztálytermi tanítás}

Vizsgálatunk fő fókusza az osztálytermi és a digitális oktatás közötti különbségek feltárása. Ezért kérdéseink egy része az osztálytermi tanításra irányult. A pedagógusok négyfokú skálán értékelték, hogy az osztálytermi tanítás során mennyire érzik sikeresnek magukat a diákok motiválásában. Négy válaszalternatíva közül választhattak: 1. egyáltalán nem, 2. többnyire nem, 3 . többnyire igen, 4 . teljes mértékben. A válaszadók $21 \%$-a teljes mértékben sikeresnek véli magát a diákok motiválásában, $73 \%$-uk jelölte a többnyire igen 
választ, és csak 6\%-uk gondolja úgy, hogy többnyire nem tudja sikeresen motiválni tanulóit jelenléti oktatás során. Nem volt olyan, aki azt mondta volna magáról, hogy egyáltalán nem sikeres az osztálytermi motiválásban. A pedagógusok többsége tehát eredményesnek véli magát a diákok motiválásában az osztálytermi oktatás során. A kétmintás t-próba szerint nincs különbség az osztálytermi motiválás eredményességében a kezdő és a gyakorlott pedagógusok között $(\mathrm{t}=-0,251 \mathrm{p}=0,802)$, legalábbis saját megítélésük szerint. Ez azt jelentheti, hogy már a kezdő pedagógusok is ugyanolyan sikeresen motiválnak, mint a gyakorlottak, vagy a fiatalkori lelkesedésük a motiválás terén akkora előnyt jelent, mint a gyakorlott pedagógusoknak a több éves tapasztalat. Az iskola településtípusa alapján sem találtunk különbséget a jelenléti oktatásban való motiválás sikerességében $(\mathrm{F}=1,567 \mathrm{p}=0,187)$.

A különböző iskolai szinteken tanító pedagógusoknak eltérő a vélekedése a motiválási módszereik sikerességéről a hagyományos, jelenléti oktatásban. $\mathrm{Az}$ alsó tagozatban tanító pedagógusok vélik magukat a leghatékonyabban motiválónak $(\mathrm{M}=3,23)$, felső tagozaton ugyanezen mutató átlaga 3,07, a középiskolában tanító pedagógusoké pedig 2,95. A diákok életkorának előrehaladtával csökkenő tendenciát mutat a pedagógusok véleménye a motiválási módszereik sikerességéről. A különbségek vizsgálatára varianciaanalízist végeztünk. Az ANOVA eredménye azt mutatja, hogy a különböző iskolai szinteken tanító pedagógusok között szignifikáns különbség van a jelenléti oktatás során érzett motiválás eredményességében ( $\mathrm{F}=3,35 \mathrm{p}=0,02)$. A Tukey's b utóelemzés szerint az alsó tagozatos tanítók és a középiskolai pedagógusok között szignifikáns különbség van, azonban a felső tagozaton tanító tanárok nem különböznek számottevően sem az alsós, sem a középiskolai pedagógusoktól. A korábbi kutatások a tanulók motiváltságában mutatnak csökkenést az iskolai évek előrehaladásával (Józsa, 2013; Józsa et al., 2014). A jelen vizsgálatunk eredménye párhuzamot mutat a korábbi vizsgálatok eredményeivel. Érdekes és fontos kérdés, milyen összefüggés lehet a kettő között? Miért csökken a tanulók motiváltsága és miért érzik magukat kevésbé hatékonynak a motiválásban a pedagógusok az iskolai évek előrehaladtával? Miként befolyásolja egymást ez a két jelenség?

\section{Digitális tanítás}

Az online oktatás esetében is négy válaszalternatívából választhattak a vizsgálatban résztvevő pedagógusok, meg kellett ítélniük, mennyire érzik hatékonynak a motivációs módszereiket. A válaszadók többsége úgy nyilatkozott (70\%), hogy az online oktatás ideje alatt is megfelelő mértékben tudta motiválni tanulóit. Azonban - az osztálytermi tanítással összehasonlítva - már többen érezték úgy, hogy nagyrészt nem tudták saját diákjaikat motiválni a digitális oktatásban: $27 \%$ szemben az osztálytermi helyzet $6 \%$-ával. Csupán egy pedagógus írta, hogy egyáltalán nem tudta motiválni tanítványait az online oktatás során, osztálytermi oktatásban egyetlen pedagógus sem érezte így. 
Nem találtunk különbséget a kezdő és gyakorlott pedagógusok között a digitális oktatásban való motiválás sikerességében $(\mathrm{t}=-0,525 \mathrm{p}=0,60)$, a kép tehát e tekintetben azonos az osztálytermi motiválással. Az iskolafokozat szerinti összehasonlításban is ugyanazt a tendenciát látjuk online oktatásnál, mint a jelenlétinél, a különbség azonban ebben az esetben nem szignifikáns az iskolafokozatok között $(\mathrm{F}=2,79 \mathrm{p}=0,07)$. Legsikeresebbnek $(\mathrm{M}=2,79)$ az alsó tagozaton tanító és legsikertelenebbnek $(M=2,52)$ a középiskolában tanító pedagógusok érzik magukat a tanulási motiváció fenntartásában. A kettő között helyezkednek el a felső tagozaton tanítók 2,69-es átlaggal.

Az iskola településtípusának vizsgálatakor nem találtunk szignifikáns különbséget a digitális oktatásban érzett motiválási módszerek sikerességében $(\mathrm{F}=1,02 \mathrm{p}=0,38)$, azonban a községi iskolák pedagógusai érezték legkevésbé hatékonynak motiválásukat $(\mathrm{M}=2,56)$. Ennek többféle oka is lehet. Egyrészt a kisebb településeken élő diákoknak rosszabb lehet az internet és eszközellátottsága, esetleg több testvér van, akikkel osztozni kellett a szobán, eszközön, így nem minden esetben tudtak részt venni a diákok az órákon. Másrészt előfordulhatott, hogy a gyermek otthoni tartózkodása a digitális oktatás során maga után vonta, hogy a szülők bevonták őket az otthoni, házkörüli munkákba vagy akár a kisebb testvérre való vigyázásba.

\section{A tanulók motiváltsága az osztálytermi és a digitális oktatás során}

A tanulók osztálytermi és digitális oktatás során érzett motiváltságát ötfokú skálán hasonlították össze a pedagógusok: a tanulók 1. sokkal kevésbé érdeklődők, mint az osztályteremben (14\%); 2. kevésbé érdeklődők, mint az osztályteremben (46\%); 3. ugyanannyira érdeklődők, mint az osztályteremben (32\%); 4. nagyobb mértékben érdeklődők, mint az osztályteremben (7\%) és 5 . sokkal nagyobb mértékben érdeklődők, mint az osztályteremben (1\%). E szerint a pedagógusok 60\%-a látja úgy, hogy a digitális oktatásban a tanulók többségének csökkent az érdeklődése a jelenléti oktatáshoz képest. Csupán 8\% azoknak a pedagógusoknak az aránya, akik a motiváció erősödését tapasztalták az online oktatás során. A kezdő és gyakorlott pedagógusok megítélésében e tekintetben nincs szignifikáns különbség $(t=0,03 \mathrm{p}=0,98)$.

A különböző iskolafokozatokban dolgozó pedagógusok megítélésében szignifikáns a különbség abban, hogy változott-e a diákok motiváltsága az online oktatásban a hagyományos oktatáshoz viszonyítva $(\mathrm{F}=4,61 \mathrm{p}=0,01)$. A különbségek értelmezését lehetővé tevő Tukey's b próba szerint az alsó tagozatos tanítók szignifikánsan kisebb motivációvesztést tapasztaltak a középiskolában tanító pedagógusokhoz képest. A felső tagozatos tanárok értékelése nem különbözik szignifikánsan sem az alsó tagozaton, sem a középiskolában tanító pedagógusokétól.

Annak megítélésére, hogy az online oktatás alatt ugyanannyira lehet-e a tanulókat motiválni, mint jelenléti oktatásban, 1-5-ig terjedő skálán kellett bejelölni a pedagógusoknak az egyetértésüket vagy egyet nem értésüket. A 
2,63-as átlag $(\mathrm{SD}=1,06)$ azt mutatja, hogy az „ugyanúgy lehet motiválni”-nál kicsivel negatívabb az összkép. Az iskolafokonkénti válaszok átlaga szerint az alsó tagozaton $(M=2,65)$ és felső tagozaton $(M=2,69)$ tanítók szerint nagyjából ugyanannyira lehet online környezetben is motiválni a diákokat. A középiskolai tanárok átlaga $(\mathrm{M}=2,38)$ azt jelzi, hogy szerintük valamivel nehezebb a motiválás a digitális oktatásban. A varianciaanalízis alapján azonban nincs szignifikáns különbség az eltérő iskolafokozaton tanító pedagógusok megítélése között $(\mathrm{F}=0,66 \mathrm{p}=0,52)$, ahogy nem találtunk számottevő eltérést a kezdő és gyakorlott tanárok között sem $(\mathrm{t}=-0,15 \mathrm{p}=0,88)$.

Az alsó- és felső tagozaton tanító, valamint a középiskolában tanító pedagógusok motivációs stratégiáinak a sikerességét a hagyományos és a digitális oktatásban páros t-próbákkal hasonlítottuk össze. Mindhárom iskolafokon tanítók úgy vélekednek, hogy a jelenléti oktatás során sikeresebben tudták motiválni tanítványaikat, mint az online oktatásban. (1. táblázat)

\section{1. táblázat}

A motiválás hatékonysága a hagyományos és digitális oktatás során a pedagógusok véleménye szerint

\begin{tabular}{|l|l|c|c|c|c|}
\hline \multirow{2}{*}{ Iskolai fokozat } & \multicolumn{1}{|c|}{ Oktatás } & \multirow{2}{*}{ Átlag } & \multirow{2}{*}{ Szórás } & \multicolumn{2}{|c|}{ Páros t-próba } \\
\cline { 5 - 6 } & & & & $|\mathbf{t}|$ & $\mathbf{p}$ \\
\hline \multirow{2}{*}{ Alsó tagozat } & Hagyományos & 3,23 & 0,49 & 7,19 & 0,001 \\
& Digitális & 2,79 & 0,50 & & \multirow{2}{*}{0,001} \\
\hline \multirow{2}{*}{ Felső tagozat } & Hagyományos & 3,07 & 0,41 & \multirow{2}{*}{0,96} & \\
& Digitális & 2,69 & 0,47 & & \multirow{2}{*}{0,016} \\
\hline \multirow{2}{*}{ Középiskola } & Hagyományos & 2,95 & 0,15 & 2,63 & \\
& Digitális & 2,52 & 0,11 & & \\
\hline
\end{tabular}

A tanulók jelenléti és online oktatása során történő motiválásának a sikeressége között szignifikáns, de csak gyenge összefüggés van $(\mathrm{r}=0,24 \mathrm{p}=0,03)$. Az eredmények különböznek az eltérő iskolai fokon tanítóknál. Csak az alsó tagozatban van szignifikáns összefüggés $(\mathrm{r}=0,26 \mathrm{p}<0,05)$, a korreláció sem a felső tagozatos $(r=-0,02 \mathrm{p}=0,88)$, sem a középiskolai pedagógusok $(\mathrm{r}=0,19$ $\mathrm{p}=0,32$ ) esetében nem szignifikáns. Ezek a korrelációk azt mutatják, hogy nem feltétlenül azok a pedagógusok érezték magukat hatékonynak a diákok motiválásában digitális környezetben, mint akik az osztálytermi környezetben.

A digitális oktatás eredményességét is ötfokú skálán értékelték a tanárok. Az alsó és felső tagozaton tanító pedagógusok véleménye megegyezik $(M=3,02)$, míg a középiskolákban oktatók véleménye szerint $(2,57)$ kevésbé mutatkozik eredményesnek a digitális oktatás, a különbség szignifikáns $(\mathrm{F}=2,64 \mathrm{p}=0,03)$. 


\section{A pedagógusok motiváltsága}

A pedagógusokat arról is megkérdeztük, hogy saját magukat mennyire érzik motiváltnak az online oktatásra. Nincs számottevő különbség a kezdő és gyakorlott pedagógusok között a saját maguk motiváltságának megítélésében $(\mathrm{t}=-0,99 \mathrm{p}=0,32)$. Nem találtunk szignifikáns eltérést sem az iskolafokozat szerinti $(\mathrm{F}=2,28 \mathrm{p}=0,11)$, sem a településtípus szerinti $(\mathrm{F}=1,30 \mathrm{p}=0,27)$ összehasonlításban.

Megvizsgáltuk, milyen összefüggés van aközött, hogy a pedagógusok mennyire érzik saját magukat motiváltnak az online oktatásra és mennyire tudják sikeresen motiválni diákjaikat a digitális oktatás során. A kettő között csak gyenge összefüggést $(r=0,21 \mathrm{p}<0,05)$ találtunk. Az iskolafokozatok szerinti összehasonlítás azt mutatja, hogy az alsó $(\mathrm{r}=0,27 \mathrm{p}<0,01)$ és felső $(\mathrm{r}=0,32 \mathrm{p}<0,05)$ tagozaton tanítóknál gyenge, de szignifikáns együttjárás van a saját motiváltság és a tanuló motiválásának sikeressége között. A középiskolai tanároknál azonban nincs összefüggés a kettő között $(r=-0,19 \mathrm{p}=0,40)$.

A digitális munkarend megvalósítása szempontjából lényeges kérdés az is, hogy mennyire érzik magabiztosnak magukat a pedagógusok az IKT-eszközök használatában, hiszen ez jelentősen befolyásolhatja azt, hogy mennyire könynyen alkalmazkodnak az online oktatáshoz, mennyire sikeresen tudják diákjaikat motiválni az órákon való részvételre és a tanulásra. A válaszadó pedagógusok 64\% többnyire, 20\%-uk pedig teljes mértékben magabiztosnak érzi magát az infokommunikációs eszközök használatában, ez együtt a válaszadók $84 \%$-a. Csupán a pedagógusok 16\%-a mondta, hogy nem magabiztos a digitális eszközök használatban. Nem találtunk szignifikáns különbséget $(\mathrm{t}=1,14 \mathrm{p}=0,26)$ a kezdő és gyakorlott pedagógusok között az IKT-eszközök használatában érzett magabiztosság terén. Az online oktatás során a tanulók motiválásában érzett sikeresség és a digitáliseszköz használatban érzett magabiztosság között nem találtunk összefüggést $(\mathrm{r}=0,01 \mathrm{p}=0,94)$, azonban a saját motiváltság és az eszközhasználat között szignifikáns kapcsolat van $(\mathrm{r}=0,26 \mathrm{p}<0,01)$. Azt feltételezhetjük, hogy az a pedagógus, aki magabiztosabbnak érzi magát a digitális eszközök használatában, az motiváltabb az online oktatásra. Azonban a tanulók motiválásának sikerességével a pedagógus eszközhasználatának a magabiztossága nincs összefüggésben $(\mathrm{r}=0,01 \mathrm{p}=0,941)$.

\section{Összegzés}

2020 tavaszán a Covid19 hatására hazánkban is előtérbe került az online oktatás, amelynek köszönhetően új dinamizmussal tört be az informatikai és módszertani innováció az oktatás mindennapjaiba, ami eddig nem látott tempójú digitális fejlődésnek tette ki az érintett pedagógusokat, diákokat és szülőket. Ezáltal a digitális oktatás egy alternatív tanulmányi úttá vált (Fekete \& Prokoláb, 2020; Vetési, 2020), de vajon hogyan alakult a diákok motiváltsága az online oktatás alatt? 
Tanulmányunk célja az volt, hogy feltérképezzük, miként vélekednek a pedagógusok a diákok online oktatás alatt tapasztalt motiváltságáról a jelenléti oktatással összehasonlítva. Kutatásunkban a pedagógusok gyakorlottsága, a tanított diákok iskolafokozata (általános iskola alsó- és felső tagozat, középiskola) és az iskola településtípusa mentén elemeztük a jelenléti és digitális oktatásban érzett különbségeket, a pedagógusok saját digitális eszközhasználatában érzett magabiztosságát és az online oktatásban a pedagógusok saját motiváltságát.

Eredményeink azt mutatják, hogy a kezdő és a gyakorlott pedagógusok egyformán sikeresnek érzik a motiválási módszereiket. Sem a jelenléti, sem a digitális oktatásban nincs különbség a kezdő és a gyakorlott pedagógusok vélekedése között. Továbbá hasonlóan vélekednek arról is, hogy a jelenléti oktatáshoz képest a diákok kevésbé motiválhatók a digitális oktatásban. Ugyancsak nem találtunk eltérést a kezdő és gyakorlott tanárok között a digitális eszközök használatának magabiztosságában annak ellenére, hogy a szakirodalom szerint a több éve pályán lévő, idősebb pedagógusok számára nagyobb kihívást jelentett a digitális oktatásra való átállás (Fekete \& Porkoláb, 2020; Kende et al., 2021). Józsa és munkatársai (2021) vizsgálatunkhoz hasonló eredményre jutottak zenepedagógusokkal végzett kutatásukban, miszerint az életkor és a pályatapasztalat alapján nincs számottevő különbség az online oktatáshoz való hozzáállásban.

Iskolafokozat szerinti összehasonlításban azt találtuk, hogy a pedagógusok mindhárom iskolai szinten sikeresebben tudják motiválni a tanítványaikat a jelenléti oktatásban a digitális oktatáshoz képest. Míg az alsó tagozatban összefüggés tapasztalható a jelenléti és az online oktatásban a motiválásban érzett sikerességben, addig a felső tagozaton és a középiskolában tanító pedagógusoknál nincs kapcsolat a kettő között. Úgy tünik, hogy a digitális térben nem feltétlenül azok a pedagógusok tudnak sikeres motiválási módszereket alkalmazni, akik az osztálytermi környezetben.

A tanulók motiváltságában csökkenés figyelhető meg az iskolafokozat, az életkor előrehaladtával mind a jelenléti, mind a digitális oktatás során, ami egybecseng a szakirodalommal (például Józsa, 2013). Eredményeink szerint nem csak a diákok motiváltságában van csökkenés, hanem abban is, hogy a pedagógusok mennyire érzik sikeresnek saját motivációs stratégiáikat. A pedagógusok úgy vélik, hogy magasabb iskolafokon kevésbé tudják motiválni a tanítványaikat, $\mathrm{s}$ mindez az osztálytermi és a digitális tanítás során is fennáll. A tanulók motiváltsága és a pedagógusok motivációs stratégiáinak csökkenő eredményessége közötti kapcsolat feltárására további vizsgálatok szükségesek.

\section{Köszönetnyilvánítás}

A kutatást az EFOP-3.1.2-16-2016-00001 számú projekt támogatta. 


\section{Irodalom}

Ambrus, B., Dallman, K. \& Indri, D. J. (2020). Szülői és diákszemmel a távoktatásról. Új Köznevelés, 76(4), 19-22. https://folyoiratok.oh.gov.hu/sites/default/files/ journals/uj_kozneveles_2020_04_online.pdf

Asztalos, R., Bánhegyi, M., Fajt, B., Pál, Á. \& Szénich, A. (2021). Hallgatói visszajelzések a kényszertávoktatásra való átállásról és a digitális módszertani megújulásról az egyetemi szaknyelvoktatásban. Iskolakultúra, 31(6), 84-100.

Cifrusz, D., Misley, H. \& Horváth L. (2020). A digitális munkarend tapasztalatai a magyar közoktatásban. Opus et Educatio, 7(3), 220-229.

Di Pietro, G., Biagi, F., Costa, P., Karpiński, Z. \& Mazza, J. (2020). The likely impact of covid-19 on education: Reflections based on the existing literature and recent international datasets. Publications Office of the European Union.

Engler, Á., Markos, V. \& Dusa, Á. R. (2021). Szülői segítségnyújtás a jelenléti és távolléti oktatás idején. Educatio, 30(1), 72-87. https://doi.org/10.1556/2063.30.2021.1.6

Err (2020). Ministry of Education asks schools to temporarily waive student assessments. https://news.err.ee/1065652/ministry-of-education-asks-schools-to-temporarilywaive-student-assessments

Fegyverneki, G. (2017). Digitáliskultúra-azonos pedagógia: a motiváció és a tananyagszerkesztés új útja? Egy digitális projekt tapasztalatai. In Polonyi, T. \& Abari, K. (Eds.), Digitális tanulás és tanitás (pp. 121-134). Debrecen.

Fehér, P. (2020). „Húsz év múlva” - A digitális oktatás helyzete, eszközei, trendjei világszerte. Gyermeknevelés Tudományos Folyóirat, 8(2), 348-370, https://doi. org/10.31074/gyntf.2020.2.348.370

Fekete, T. \& Porkoláb, Á. (2020). Karanténpedagógia a magyar közoktatásban. Iskolakultúra, 30(9), 96-112.https://doi.org/10.14232/ISKKULT.2020.9.96

Garcia, E. \& Weiss, E. (2020). Access to online learning amid coronavirus is far from universal, and children who are poor suffer from a digital divide. Working Economics Blog.https://www.epi.org/blog/access-to-online-learning-amidcoronavirus-and-digital-divide/

Gliner, J. A., Morgan, G. A. \& Leech, N. L. (2017). Research Methods in Applied Settings: An integrated approach to design and analysis.Routledge/Taylor \& Francis.

Hartnett, M. (2016). Motivation in online education. Springer. https://doi. org/10.1007/978-981-10-0700-2

Ithriah, S. A., Ridwandono, D. \& Suryanto, T. L. M. (2020). Online Learning SelfEfficacy: the role in E-Learning Success. Journal of Physics: Conference Series, 1569, 022053. https://doi.org/10.1088/1742-6596/1569/2/022053 https:// iopscience.iop.org/article/10.1088/1742-6596/1569/2/022053/pdf

Jakab, G. (2020). ISKOLA - járvány idején (1. rész). Iskolakultúra, 30(9), 64-76. https://doi.org/10.14232/ISKKULT.2020.9.64 
Józsa, G., Szűcs, T. \& Váradi, J. (2021). A zenetanárok digitális attitűdjére ható tényezők vizsgálata. In Váradi, J. (Ed.), Az online tér megjelenése a zenemüvészeti oktatásban és a hangversenylátogatásban. (megjelenés alatt)

Józsa, K. (2013). Az elsajátítási motiváció életkori változása egy longitudinális vizsgálat tükrében. In Molnár, G \& Korom, E. (Eds.), Aziskolai sikerességet befolyásoló kognitív és affektív tényezők értékelése (pp. 85-104). Nemzedékek Tudása Tankönyvkiadó.

Józsa, K., Barrett, K. C., Amukune, S., Calchei, M., Gharib, M., Iqbal Hashmi, S., Podráczky, J., Nyitrai, Á. \& Wang, J. (2020). Implications of the DMQ for Education and Human Development: Culture, Age and School Performance. In Morgan, G. A., Liao, H.-F. \& Józsa, K. (Eds.), Assessing Mastery Motivation in Children Using the Dimensions of Mastery Questionnaire (DMQ) (pp. 133-158). Szent István Egyetem.

Józsa, K. \& Pasztendorf, G. (2021). Az olvasástanítás eredményessége az iskola kezdő szakaszában a Covid19 időszaka alatt: a pedagógusok és a szülők megítélése. Gyermeknevelés Tudományos Folyóirat, (9)2, 131-144.

Józsa, K., Wang, J., Barrett, K. C. \& Morgan, G. A. (2014). Age and cultural differences in mastery motivation in American, Chinese, and Hungarian schoolage children. Child Development Research, Article ID 803061, 1-16. https://doi. org/10.1155/2014/803061

Kassa, T. (2020). Digitális oktatás: (Hogyan) lehet jól csinálni? https://www.youtube. com/watch?v=6dpAGgyW_TU (2020.04.14.)

Keller, J. M. \& Suzuki, K. (2004). Learner motivation and e-learning design: A multinationally validated process. Journal of Educational Media, 29(3), 229-239. https://doi.org/10.1080/1358165042000283084

Kende, Á., Messing, V. \& Fejes, J. B. (2021). Hátrányos helyzetű tanulók digitális oktatása a koronavírus okozta iskolabezárás idején. Iskolakultúra, 31(2), 76-97. https://doi.org/10.14232/ISKKULT.2021.02.76

Kyewski, E. \& Krämer, N. C. (2018). To gamify or not to gamify? An experimental field study of the influence of badges on motivation, activity, and performance in an online learning course. Computers E Education, 118, 25-37. https://doi. org/10.1016/j.compedu.2017.11.006

Lénárd, A. (2020). Digitális technológia a tanítási órákon. In Katona, N. (Ed.), Digitális pedagógia a közoktatásban (pp. 41-44). Eszterházy Károly Egyetem. https://www.oktatas2030.hu/wp-content/uploads/2020/10/digitalis-pedagogiaa-kozoktatasban.pdf

Lepper, M. R. (1985). Microcomputers in education: Motivational and social issues. American Psychologist, 40(1), 1-18. https://doi.org/10.1037/0003-066X.40.1.1

Mihály, I. (2006). Az otthon tanulás gyakorlata; a múlt, a jelen - és a jövő? Új Pedagógiai Szemle, 56(6), 83-90.

Molnár, Gy. \& Csapó, B. (2019). A diagnosztikus mérési rendszer technológiai keretei: Az eDia online platform. Iskolakultúra, 29(4-5), 16-32. https://doi. org/10.14232/ISKKULT.2019.4-5.16 
Molnár, Gy., Hódi, Ágnes, Ökördi, R. \& Mokri, D. (2021). A koronavírus-járvány okozta rendkívüli oktatási helyzet hatása 2-8. évfolyamos diákok tudás- és képességszintjére az olvasásszövegértés, a matematika és a természettudományok területén. Iskolakultúra, 31(2), 3-22. https://doi.org/10.14232/ISKKULT.2021.02.3

Molnár Gy., Turcsányi-Szabó, M. \& Kárpáti, A. (2020). Digitális forradalom az oktatásban - Perspektívák és dilemmák. Magyar Tudomány, 181(1) 59-67.

N. Kollár, K. (2021). Az online oktatás tapasztalatai és gyakorlata a pedagógusok nézőpontjából. Iskolakultúra, 31(2), 23-53. https://doi.org/10.14232/ ISKKULT.2021.02.23

Nágel, Zs. (2012). Otthonoktatás. Tani-tani Online, http://www.tani-tani.info/ otthonoktatas_1

Námesztovszki, Zs., Glušac, D. \& Branka, A. (2013). A tanulók motiváltsági szintje egy hagyományos és egy IKT eszközökkel gazdagított oktatási környezetben. OktatásInformatika, 4(1-2). http://www.oktatas-informatika.hu/2013/03/namesztovszkizsolt-glusac-dragana-branka-arsovic-a-tanulok-motivaltsagi-szintje-egyhagyomanyos-es-egy-ikt-eszkozokkel-gazdagitott-oktatasi-kornyezetben/

Porubčanová, D., Geršicová, Z., Bočková, K., Pasternáková,1., Barnová, S., Rochovská, I., Dolinská, E., Dudek, M. \& Szőköl, I. (2021). Educational challenges in subject didactics education in the context of home education. STS Science Centre, Ltd. in coedition with KEY Publishing.

Prievara, T. (2020). Pedagógiai tervezés. In Katona, N. (Ed.), Digitális pedagógia a közoktatásban (pp. 14-20). Eszterházy Károly Egyetem. https://www.oktatas2030. hu/wp-content/uploads/2020/10/digitalis-pedagogia-a-kozoktatasban.pdf

Ray, B. D. (2017). A systematic review of the empirical research on selected aspects of homeschooling as a school choice. Journal of School Choice, 11(4), 604-621, https://doi.org/10.1080/15582159.2017.1395638

Shroff, R. H. \& Vogel, D. R. (2009). Assessing the factors deemed to support individual student intrinsic motivation in technology supported online and faceto-face discussions. Journal of Information Technology Education, 8, 59-85.

Szabó, N., Józsa, K. \& Janurik, M. (2021). Digitális eszközök használata az énekzene órán: egy első osztályos tanulókkal folytatott kísérlet eredményei. Magyar Pedagógia, 121(1), (megjelenés alatt).

Szilveszter, Á, Kassai, R. Takács, Zs. \& Futó, J. (2021). Az otthoni tanulás sikerességét bejósló tényezők a Covid-19 okozta vészhelyzet miatt kialakított digitális munkarendben eltérő szocioökonómiai helyzetű családok esetében. Educatio, 30(1), 88-102. https://doi.org/10.1556/2063.30.2021.1.7

Tóth, A. (2019). Ezek a tanárok hiányoznak az iskolákból: miért választja ilyen kevés férfi ezt a pályát? https://eduline.hu/kozoktatas/20190110_meg_mindig_ keves_a_ferfi_tanar_az_iskolakban (2019.12.12.) 
Török, B. (2013). Az IKT oktatási szerepének változása az „Európa 2020” fejlesztési stratégia kontextusában. Új Pedagógiai Szemle, 63(11-12), 29-38. https://epa. oszk.hu/00000/00035/00161/pdf/EPA00035_upsz_2013_11-12_029-039.pdf

Váradi, J. \& Józsa, G. (2021). A kutatás előzménye, mintája és módszere. In Váradi J.(Ed.), Azonline térmegjelenése a zenemüvészeti oktatásbanés a hangversenylátogatásban. (megjelenés alatt)

Veszprémi, A. (2020). (Azért is) fókuszban az otthonoktatás - Beszámoló a PedLabor 2020. márciusi konferenciájáról. Új Pedagógiai Szemle, 70(7-8), 145-159. http:// upszonline.hu/index.php?article $=700708014$

Vetési, E. (2020). A digitális tananyagfejlesztés speciális szempontjai. Gyermeknevelés Tudományos Folyóirat,8(2), 192-201. https://doi.org/10.31074/ gyntf.2020.2.192.201

Wighting, M. J., Liu, J. \& Rovai, A. P. (2008). Distinguishing sense of community and motivation characteristics between online and traditional college students. Quarterly Review of Distance Education, 9(3), 285-295. 


\section{Józsa, G., Karáné Miklós, N. \& Józsa, K.}

\section{Motivating students during Covid19 school closures - Teachers' experiences}

The study examines learning motivation during online education introduced due to the Covid19 situation. The questionnaire was filled out by 160 teachers who were from the junior and senior section of elementary schools and also from secondary schools. The research aimed to explore teachers' views on students' motivation concerning digital education. Students' motivation during classroom learning was compared with their motivation during digital education based on the perceptions of teachers. We also examined teachers' beliefs concerning the effectiveness of their motivating strategies during online education. We analyzed the differences in the effectiveness of motivational methods in the junior and senior elementary schol and also in secondary school. In addition, we looked at teachers' views on their own motivation in relation to digital education, and its association with the motivation of their students. Variables included the students' level at school, proficiency (beginner, proficient) and the confidence of teachers in using ICT devices, as well as the type of the settlement where the school was situated.

Keywords: digital education, learning motivation, teachers' beliefs

Józsa Gabriella: https://orcid.org/0000-0001-9134-1764

Karáné Miklós Noémi: https://orcid.org/0000-0003-3334-2093

Józsa Krisztián: https://orcid.org/0000-0001-7174-5067 